\title{
Redefining Water Security through Social Reproduction: Lessons Learned from Rajasthan's 'Ocean of Sand'
}

\author{
Michael Mascarenhas
}

\begin{abstract}
One of the most urgent challenges facing the world today is ensuring local water security under rapid climate variability and change. This is of particular importance in a country like India, where over half of the people are involved in farming, and agricultural losses due to climate change are estimated to be as high as 30 per cent by 2080 . This ethnography in the arid village of Bhiwadi, West Rajasthan empirically links the reintroduction of local water harvesting technologies with the building of sustainable social reproduction in subsistent communities. By emphasising both the role of gender and the informal economy - and institutions - this ethnography provides a more thorough picture of the individuals and collective actors involved in localised and resilient technologies within global economic and climatic processes.
\end{abstract}

\begin{abstract}
1 Introduction
Threats to water security from climate uncertainty at local and global scales have emerged as a major social and ecological concern. For the purposes of this analysis I use the United Nations definition of water scarcity. According to a report by the Food and Agriculture Organization (FAO 2006: 2) water scarcity is 'the point at which the aggregate impact of all users impinges on the supply or quality of water under prevailing institutional arrangements to the extent that the demand by all sectors, including the environment, cannot be satisfied fully'. Water security, therefore, is the environmental and social conditions that ensure adequate supply of water and improved sanitation. The challenge, however, becomes even more daunting when one reflects on current food security in India: 195 million under-fives are malnourished, of which 130 million are underweight, and one-in-three women and onein-four men also suffer from malnutrition (Patnaik 2010); and this, in an economy where 60 per cent of the population is involved in farming, and agricultural losses due to climate change are predicted to be as high as 30 per cent by 2080 (Cline 2008).
\end{abstract}

The goal in this article is threefold. First, is to outline the extent to which local knowledge is utilised in adapting to new environmental conditions under climate uncertainty in rural and drought-prone West Rajasthan. This goal contributes to a well-established discursive critique of development and expertise - where subsistent farmers (in rural India) are seen as helpless, lacking the skills necessary to survive without Western knowledge and technologies (Marchand 2002; Parpart 2002; Harding 1998, 1991; Escobar 1995; Marchand and Parpart 1995; Haraway 1991; Peet and Watts 1996). Second, is to illustrate the role of informal institutions in nurturing practices that advance both household social reproduction and women's status within the community. This goal expands the possible forms of interventions and resistance, beyond those offered in the conventional political economy, by making visible the role of women's work in the sustainable management of shared resources under climate uncertainty (Nightingale 2006; Bergeron 2001; Freeman 2001; Salleh 1997; Massey 1994). Third, is to extend the analysis of traditional localised water schemes in rebuilding community sustainability. In spite of their positive impact on local communities these localised water schemes are rarely recognised by government agencies and non-profit organisations as legitimate technology, and therefore, are rarely understood or

IDS Bulletin Volume 43 Number 2 March 2012 (c) 2012 The Author. IDS Bulletin (c) 2012 Institute of Development Studies Published by Blackwell Publishing Ltd, 9600 Garsington Road, Oxford OX4 2DQ, UK and 350 Main Street, Malden, MA 02148, USA 
supported (Strang 2004; Swyngedouw 2000). It is for this reason that Anil Agarwal and Sunita Narain (1997) describe knowledge of the traditional water harvesting systems of India as a 'dying wisdom'. As a result of this narrow technical interpretation, irrigation projects in India exclude local communities from direct participation in project design, and more often reinforce, rather than relieve, existing patterns of inequity, inefficiency, and environmental degradation (Phadke 2005; Vaidyanathan 1999).

These three developments embody the intersecting effects and consequences of climate change and other human-induced changes to water services in rural and subsistent communities in Rajasthan - an effect that has amplified given rapid climate variability and change. This approach offers a sociological logic that recognises both the validity of cultural and social difference between and amongst particular social groups, and the multidimensional and transgressive nature of water problems. The goal is to not to valorise either experience or the local, but 'to reveal a local that is constitutively global but whose engagements with various global imperatives are the material forms and practices of situated knowledge' (Katz 2001a: 1214).

\section{Review of literature}

A recent United Nations Human Development Report (UNDP 2006) suggested that power, poverty and inequality are at the heart of today's global water crisis. This form of environmental inequality is particularly destructive for poor and subsistent women in the South because they continue to shoulder the burden of their households' reproduction and wellbeing (Mascarenhas 2008; Bergeron 2001; Freeman 2001; Katz 2001b; Merchant 1996; Mies 1993; Shiva 1988). Neglecting to discuss women's role in water and food security is a huge oversight when one considers that women worldwide are estimated to perform about two-thirds of the world's work (York and Egras 2011; UNICEF 2004). This oversight is often exacerbated by the fact that many development scholars continue to use formal economic data, such as national debt and gross national product (GNP), instead of looking at the role of the informal economy, where women's subsistent work is most vital. According to the United Nations Human Settlements Programme (UN-Habitat 2003) informal workers make up about two-fifths of the economically active population of the developing world. The UN report, The Challenge of the Slums: Global Report on Human Settlements 2003, goes on to cite research findings that estimate the informal economic activity to be 33-40 per cent of urban employment in Asia, 60-75 per cent in Central America, and 60 per cent in Africa (UN-Habitat 2003).

Recent scholarship, most notably the Fourth Assessment Report of the Intergovernmental Panel on Climate Change (Rosenzweig et al. 2007), concluded that 'warming of the climate system is unequivocal, as is now evident from observations of increases in global average air and ocean temperatures, widespread melting of snow and ice, and rising global average sea level'. However, what is less clear, the Intergovernmental Panel on Climate Change (IPCC) observed, is how a rapidly changing climate will impact regional and local conditions. 'Documented evidence of adaptation to regional climate trends in the highly managed systems of agriculture and forestry have begun to emerge', the report noted; however, there is a notable lack of geographical balance in the data and literature on observed changes from developing countries (Rosenzweig et al. 2007: 117).

Recently completed research by Aneel Salman (2010) assessed the effects of climate change on the livelihoods and wellbeing of residents of Keti Bunder, a group of coastal villages east of Karachi, Pakistan. A striking conclusion from this empirical study was that the local communities were entirely aware of both the human and natural impacts of climate change in the region in spite of the fact that they were often helpless to take action to alter their situations. However, when these communities found institutional support, in the form of local self-help organisations or non-governmental partners, they were able to translate their traditional knowledge into practices that were resilient to both climate-induced changes and economic stressors. The large majority of the world's poor, Salman (2010) argues, continue to find ingenious methods to cope with their growing lack of opportunities for survival, even when faced with adverse calamities and disasters. Learning how they cope, Salman (2010) argues, is precisely what is needed to better understand the complex problems of climate change for the majority of the world's poor. 
This work points to the importance of informal and self-organising institutions in the sustainable management of shared resources under climate uncertainty. Elinor Ostrom and colleagues have argued for a third path (different from the normal market or state approaches) towards development, one that relies on the ability of local institutions, such as town or village committees, neighbourhood organisations, churches, or any other voluntary community association, and locally motivated governing rules to govern sustainably (Ostrom 2009, 2005, 1999, 1990; Ostrom et al. 1994, 1993). In a similar vein, Bina Agarwal at the Institute of Economic Growth, Delhi, argues for a 'group approach' for alleviating rural poverty, and especially poverty among women. In keeping with principles emphasised in a human rights approach to development, Agarwal argues that a 'group approach' must be 'small-sized, voluntary, socioeconomically homogeneous and participatory in decision-making' (Agarwal 2010: 64). These locally motivated governing rules not only form the foundation of community capacity-building initiatives, Hussain and Hussain (2006) argue, but also create a sense of community empowerment and freedom, which can be of particular consequence for women in rural India, who continue to constitute most of the growing landlessness and unpaid labor force.

Informal and self-organising groups are key to local sustainability initiatives because they form the foundation upon which social reproduction can be built. Social reproduction at the household level means the direct costs associated with the activities that maintain an individual's, household's or group's conditions (e.g. child care, education, and health care costs). At a larger level this includes the continuance of human resources, goods, and services that do not enter the market. These costs may include the passing on of languages, knowledges, histories, and cultural practices from one generation to another, or the training of specific subsistent practices, such as the attainment of food, clothing, and shelter. At a meta-level, social reproduction also includes the maintenance of particular environmental conditions on which the specific social activities of reproduction are secured, such as clean air and drinking water, proper sanitation, safe food and housing, and access to health care.

This 'messiness' or complexity of many activities directed toward social reproduction renders its contribution to human health and wellbeing very difficult to measure, either conceptually or in practice. Unlike economic production, this purposive and meaningful social activity does not enter into formal accounting mechanisms like the GNP, and rarely enters into cost benefit analyses or policy discussions concerning the impacts of maintaining (or terminating) particular social or environmental programmes. Furthermore, because political economy approaches to gender and development display a distinct preference to theorise the nation-state as women's primary source of resistance to the negative aspects of globalisation, they most often overlook the work of informal institutions, such as town or village committees, neighbourhood organisations, and women's self-help groups, as possible forms of interventions and resistance, beyond those offered in the conventional political economy discourses. This exclusive emphasis on the nation-state and economic production has limited the range of potential options that can be meaningfully discussed in the feminist economic literature (York and Egras 2011; Nightingale 2006; Bergeron 2001; Freeman 2001; Salleh 1997; Massey 1994).

This review points to the importance and necessity of learning from rural communities living in or near areas that are disproportionately impacted by climate change. Because local impacts are local we need more local analysis to better understand the instances when informal institutions and local participation engender long-term community sustainability. This review draws attention to the crucial roles that gender, local knowledges, and informal economic practices can play within the larger political economic structures to bring about local sustainable practices.

\section{The ethnography}

An ethnographic method was applied to data collection for this study during 2009.

Ethnography, according to Hammersley and Atkinson (1995: 2), 'bears a close resemblance to the routine ways in which people make sense of the world in everyday life'. It is both a matter of collecting data and collecting stories about the world we live in and the subject matter we care about (Grindstaff 2002).

Access to the Meo community was arranged by the Sir Syed Trust (SST), a local nongovernmental organisation (NGO) that works for the betterment of poor women and destitute 
poor families in rural areas in Rajasthan and Uttar Pradesh. This work would not have been possible if it wasn't for the generous help of Asif Zaidi, the Executive Director of the Sir Syed Trust. For over 20 years he was the State Program Director for Pradan, a NGO whose mission is to conquer economic poverty through enhancing the livelihood capabilities of the poor and giving them access to sustainable incomeearning opportunities. In 2007 he set up his own NGO (Sir Syed Trust) to work specifically with marginalised people in the Alwar district of Rajasthan.

There are many faces to the marginalisation of the Meo community near the village of Bhiwadi. There is the political and social marginalisation that comes with being a Muslim community in India. There is the marginalisation that comes with being of scheduled caste (SC), scheduled tribe (ST) caste or other backward caste (OBC). The majority (67 per cent) of the 1,600 families that belong to this community are of made up of OBC, while about a quarter (23 per cent) are comprised of SC and ST (with 10 per cent being classified as 'other'). Their religious and caste compositions, Zaidi explains, ensure that 'they are always fighting with the state'. For example, the government's attempts to develop common lands through various urbanisation and development initiatives along with its insistence to exclude the Meo community from government programmes (such as irrigation sprinklers) and eligible subsidies has ensured that this community is left to its own devices. This historical and political context has been a major obstacle in the development of local and sustainable pathways to water security and improved sanitation. Additional social challenges come from the fact that in the community the literacy rate is approximately 12 per cent, the average marital age is 12 (with an average family size of six to eight), and the average education is between grades three and four. This is particularly true for girls, who are pulled out of school to help with the social reproduction of community affairs.

The State of Rajasthan has 31 districts, of which 13 are located on the west of the Aravali Mountains and the rest on the east and south. The village of Bhiwadi is located in Alwar, one of the 19 districts located to the east of the Aravali Mountains. Although varying greatly from east $(16 \mathrm{~cm})$ to west $(60 \mathrm{~cm})$, the Rajasthan's average rainfall is the lowest in India. The village of Bhiwadi is one of the 'most privileged' areas in the desert - receiving between $50-55 \mathrm{~cm}$ of rain per year (Mishra 2007).

In the first visit to the community in June 2009 the midday temperature reached $48^{\circ} \mathrm{C}$. 'Going outside [in the summer months] is becoming difficult',

Zaidi tells me. This extreme rise in temperature is a fairly recent phenomenon. He explained that previously wind and then showers followed the rise in temperature in the summer months. However, this year, as in the last two or three, there were no showers. In addition, Zaidi said, the number of rainy days during the monsoon season is shrinking: 'Last year we had between 25 and 30 rainy days', whereas 40-45 days of rain is more typical in this area. Furthermore, 'Earlier we experienced widespread rains. Today, rain is more localised. Half the village is dry, while the other half is wet'. Unseasonable high temperatures combined with erratic rain patterns has also affected soil moisture levels through increased evapotranspiration and reduced tree cover, ultimately undermining longterm food and water security.

One particularly striking example of how climate change is changing the community's social structure is in the recent loss of marriages. Because climate change is adversely impacting the community's ability to subsist, many boys and men have been forced to migrate to Delhi or Jaipur for wage labour. Their absence, which usually turns out to be long term or permanent, has upset the rituals of courtship, and ultimately marriage patterns in the village. This loss of male heads of households has also had a detrimental impact on the community's ability to challenge external pressures of urbanisation and industrialisation, and the government's efforts to develop common lands. Furthermore, as men move out of agriculture, those left behind on farms are increasingly women, leading to a feminisation of agriculture (Agarwal 2010).

\section{Building resilient technologies under climate uncertainty}

These climatic changes have not gone unnoticed. 'Villagers are aware that something is happening,' Zaidi confirmed. In particular, the woman's self-help group meets every Saturday morning to talk about personal and community concerns. These conversations occur alongside other conversations about environmental 
conditions, poverty in the community, and the role of government in their lives. The blending of stories and narratives about larger

environmental and global concerns with personal troubles for life and livelihood has given rise to a new form of local community activism. However, this unique social and environmental movement bears little resemblance to environmentalism or class and gender struggles of the developed world (Roberts 2009; Ignatow 2008; Davis 2004).

For example, over time, and with leadership from the woman's self-help group, community members produced an elaborate plan to harvest rainwater to support rain-fed agriculture on their commonly shared lands. The traditional practice of paal-making (a local word meaning earthen embankments) has featured prominently in previous organised efforts to combat both natural and human-induced changes to their water supply. Before the Partition of 1947, Zaidi explained, rural land and the water structures that allowed for settlement in deserts were owned in common. However, after Partition, land and the water structures that dotted the landscape became owned by particular (powerful) families, which disbanded the public ownership arrangements and terminated the informal community practices of building and maintaining technologies of rainwater harvesting. The compromised water quality and quantity that resulted forced many communities to migrate.

Paal-making is the practice of terracing the desert landscape to both store rainwater and channel runoff that travels from the nearby hills. During the wet season a khadeen - a sort of temporary lake - forms behind the paal. Over time these small lakes slowly dry up and in so doing they both replenish the groundwater and humidify the parched soil. This slow leaching process ensures that the soil of the khadeen is exceptionally rich in nutrients and agro-livestock interventions are introduced to increase soil compatibility. The combination of nutrients and humidity in the soil allows for wheat, barely, maize, and mustard to be grown in the 'dried up' khadeen.

Transacting the paal are smaller earthen embankments known as dhora or toba. These embankments contain and channel the surface runoff across catchment areas. Smaller embankments (johards) terrace the landscape to direct the water where it is needed. Lastly, field burns separate half-acre plots that are managed by six to eight households. The steady supply of water from the revival of traditional water harvesting techniques has also lead to the renaissance of traditional agro-horticultural and floricultural practices. The planting of local trees gives shade as well as fuel and fodder for livestock. The timber is also used as a basic building material as well as for the carving of crafts and toys. In addition to planting ornamental trees, a large variety of flowers and medicinal plants are grown along with fruits and vegetables. Excess produce, about 30-40 per cent of the total yield, is sold to local markets, and the revenue generated from these renewed cultivating options have been instrumental in increasing both community resilience and gender empowerment within and for this Meo community.

\section{Informal institutions, social reproduction, and women's empowerment}

Informal and self-organising groups are critical to local sustainability initiatives because they form the foundation upon which social reproduction can be built. In the arid village of Bhiwadi, West Rajasthan, concerns of personal and community stability and sustainability under climate uncertainty has produced a kind of informal survivalism that firmly establishes a connection between women's empowerment and environmental politics.

One form of empowerment is evidenced by the changed roles of women in the community. The women's self-help group (SHG) meets every Saturday morning to contribute their ten rupees to the community's bank and discuss issues that affect them both personally and collectively. 'Women's savings', Zaidi explains, 'has brought about remarkable changes... Before men would go out and buy seeds and fertiliser, and women had no say in the decision. Now men have to negotiate with women.' Through their savings scheme women have been able to leverage the authority and 'start asking questions'. In addition to asking questions, women are also making decisions about how money will be spent in the community. For example, when needed, a woman may ask to take a loan for medical reasons. Women were also engaging in larger 'policy' decisions (which traditionally had been exclusively male dominated) about livestock interventions, crop selection, and market distribution that affect both the daily and longterm social reproduction of their communities. 
However, an equally important personal form of women's empowerment is also resulting from the interpersonal character of the self-help group. In addition to talking about community issues each Saturday, women also talked about other issues, specifically their personal or family concerns.

This form of interpersonal communication works to transform personal adversity, and the stigma attached to it, into shared histories and village concerns that speak to larger village issues of gender, power, and inequality: Women are becoming advocates for social change and a real role model in the community.

Lastly, the women's self-help group has also influenced governmental change. For example, government programmes, such as the Rural Livelihoods Project, allow SHGs in rural India to borrow up to four times of their original investment. And while the village has not exercised this governmental scheme its eligibility stands in stark contrast to its previous marginalisation by government programmes. Furthermore, the village's participation in one of approximately 69,000 SHG federations in India gives it real political power to negotiate with policymakers and governments, NGOs, and others who are increasingly turning to the SHG model as a means to empower women, reduce poverty, and advance long-term community sustainability in the South.

\section{Rethinking the ecologies of development and gender}

Overcoming historical legacies of colonialism and development by rebuilding their old technologies and modifying contemporary practices to create

\section{References}

Agarwal, B. (2010) 'Rethinking Agricultural Production Collectivities', Economic and Political Weekly xlv.9: 64-78

Agarwal, A. and Narain, S. (1997) Dying Wisdom. Rise, Fall, and Potential of India's Traditional Water Harvesting Systems, New Delhi, India: Centre for Science and Environment

Bergeron, S. (2001) 'Political Economic Discourses of Globalization and Feminist Politics', Signs 26: 983-1006

Cline, W.R. (2008) Global Warming and Agriculture: Impact Estimates by Country, Washington DC: Peterson Institute for International Economics

Davis, M. (2004) 'Planet of Slums: Urban Involution and the Informal Proletariat', New Left Review 26: 5-34 hybrid (new and old) solutions to water security and community capacity building takes time and energy. In addition to previous institutional neglect encouraged by earlier governance systems, today encroachment from urbanisation and development strategies continue to threaten the complete revival of the entire paal system in this region. However, the practices and positions outlined above - the derivative of the differently situated knowledges of community members - continue to be an empowering force for social change and a pathway to water security (Haraway 1991). In particular, the paradigm of water harvesting, as opposed to 'extracting' water or 'piping' water from elsewhere has been instrumental in translating local knowledges into practices that are increasingly resilient to both ecological (climateinduced) and sociological stressors.

According to the IPCC, the complex and uneven consequences of climate change will increase the need for 'additional timely and effective adaptation' by governments, communities, and individuals everywhere (IPCC 2009: 2). This research empirically links the practices of SHGs with the social reproduction of life and livelihood in subsistent communities. In so doing it presents an alternative pathway to water security that leaves scope/space for imagining agency and practices of resistance within conditions of increasing climate vulnerability. By emphasising both the role of gender and the informal economy, this ethnography provides a more thorough picture of the individuals and collective actors involved in localised social change within global economic and climatic processes.

Escobar, A. (1995) Encountering Development: The Making and the Unmaking of the Third World, Princeton NJ: Princeton University Press

FAO (2006) Coping with Water Scarcity: A Strategic Issue and Priority for System-Wide Action, Rome: Food and Agriculture Organization of the United Nations

Freeman, C. (2001) 'Is Local: Global as Feminine: Masculine? Rethinking the Gender of Globalization', Signs 26: 1007-37

Grindstaff, L. (2002) The Money Shot: Trash, Class, and the Making of TV Talk Shows, Chicago: University of Chicago Press

Hammersley, M. and Atkinson, P. (1995) Ethnography: Principles in Practice, New York: Routledge 
Haraway, D. (1991) 'Situated Knowledges: The Science in Feminism and the Privilege of Partial Perspective', in D. Haraway (ed.), Simians, Cyborgs and Women, London: Routledge

Harding, S. (1998) Is Science Multicultural?: Postcolonialisms, Feminisms, and Epistemologies, Bloomington IN: Indiana University Press

Harding, S. (1991) Whose Science, Whose Knowledge?, Ithaca: Cornell University Press

Hussain, A. and Hussain, S. (2006) 'Devolution for Empowering the Poor: Institutions, Norms and Power', The 22nd Annual General Meeting and Conference of Pakistan Society of Development Economists, Islamabad: Pakistan Institute of Development Economics

Ignatow, G. (2008) 'Transnational Environmentalism at Europe's Boundaries Identity Movements in Lithuania and Turkey', Current Sociology 56: 845-64

IPCC (2009) Managing the Risks of Extreme Events and Disasters to Advance Climate Change Adaptation, IPCG-XXX/Doc.14, Geneva, Switzerland: International Panel on Climate Change Secretariat

Katz, C. (2001a) 'On the Grounds of Globalization: A Topography for Feminist Political Engagement', Signs: Journal of Women in Culture and Society 26.4: 1213-34

Katz, C. (2001b) 'Vagabond Capitalism and the Necessity of Social Reproduction', Antipode 33: 709-28

Marchand, M. (2002) 'Engendering Globalization in an Era of Transnational Capital', in K. Saunders (ed.), Feminist PostDevelopment Thought, London: Zed Books

Marchand, M. and Parpart, J. (1995) Feminism, Postmodernism, Development, London: Routledge

Mascarenhas, M. (2008) 'Environmental Inequality and Environmental Justice', in K. Gould and T. Lewis (eds), Twenty Lessons in Environmental Sociology, New York: Oxford University Press

Massey, D. (1994) Space, Place, and Gender, Minneapolis: University of Minnesota Press

Merchant, C. (1996) 'The Death of Nature: Women and Ecology in the Scientific Revolution', in C. Merchant (ed.), Earthcare: Women and the Environment, New York: Routledge

Mies, M. (1993) 'The Need for a New Vision: The Subsistence Perspective', in M. Mies and V. Shiva (eds), Ecofeminism, London: Zed Books

Mishra, A. (2007) Rajasthan Ki Rajat Boonde [The Radiant Raindrops of Rajasthan], Rajasthan,
India: Research Foundation for Science Technology and Ecology, Gandhi Peace Foundation

Nightingale, A. (2006) 'The Nature of Gender: Work, Gender, and Environment', Environment and Planning D: Society and Space 24: 165-85

Ostrom, E. (2009) A Polycentric Approach for Coping with Climate Change, Policy Research Working Paper 5095, Washington DC: World Bank Development Economics Office of the Senior Vice President and Chief Economist

Ostrom, E. (2005) Understanding Institutional Diversity, Princeton NJ: Princeton University Press

Ostrom, E. (1999) 'Coping with Tragedies of the Commons', Annual Review of Political Science 2: 493-535

Ostrom, E. (1990) Governing the Commons: The Evolution of Institutions for Collective Action, New York: Cambridge University Press

Ostrom, E.; Gardner, R. and Walker, J. (1994) Rules, Games, and Common-Pool Resources, Ann Arbor MI: University of Michigan Press

Ostrom, E.; Schroder, L. and Wynne, S. (1993) Institutional Incentives and Sustainable Development: Infrastructure Policies in Perspective, Boulder CO: Westview Press

Parpart, J. (2002) 'Lessons from the Field: Rethinking Empowerment, Gender and Dvelopment from a Post-Development Perspective', in K. Saunders (ed.), Feminist Post Development Thought, London: Zed Books

Patnaik, B. (2010) Office of the Commissioners to India's Supreme Court, New York

Peet, R. and Watts, M. (1996) 'Liberation Ecologies: Environment, Development, Sustainability, and Environment in an Age of Market Triumphalism', in R. Peet and M. Watts (eds), Liberation Ecologies: Environment, Development, Social Movements, New York: Routledge

Phadke, R. (2005) 'People's Science in Action: The Politics of Protest and Knowledge Brokering in India', Society and Natural Resources 18: 363-75

Roberts, J.T. (2009) 'Climate Change: Why the Old Approaches aren't Working', in K. Gould and T. Lewis (eds), Twenty Lessons in Environmental Sociology, New York: Oxford University Press

Rosenzweig, C.; Casassa, G.; Karoly, D.J.; Imeson, A.; Liu, C.; Menzel, A.; Rawlins, S.; Root, T.L.; Seguin, B. and Tryjanowski, P. (2007) '2007: Assessment of Observed Changes and 
Responses in Natural and Managed Systems', in M.L. Parry, O.F. Canziani, J.P. Palutikof, P. J.v.d. Linden and C.E. Hanson (eds), Climate Change 2007: Impacts, Adaptation and Vulnerability. Contribution of Working Group II to the Fourth Assessment Report of the Intergovernmental Panel on Climate Change, Cambridge: Cambridge University Press: 79-131

Salleh, A. (1997) Ecofeminism as Politics: Nature, Marx, and Postmodern, London: Zed Books

Salman, A. (2010) 'Sustainable Well-being and Climate Change in Pakistan - The Case of Keti Bunder's Coastal Ecosystem', PhD thesis, Rensselaer Polytechnic Institute, Troy, New York

Shiva, V. (1988) Staying Alive: Women, Ecology and Survival in India, New York: Zed Books

Strang, V. (2004) The Meaning of Water, Oxford: Berg Publishers

Swyngedouw, E. (2000) 'Authoritarian Governance, Power, and the Politics of
Rescaling', Environment and Planning D: Society and Space 18: 63-76

UNDP (United Nations Development Programme) (2006) Beyond Scarcity: Power, Poverty and the Global Water Crisis, Human Development Report, New York: Palgrave Macmillan

UN-Habitat (United Nations Human Settlements Programme) (2003) The Challenge of the Slums: Global Report on Human Settlements 2003, London: Earthscan

UNICEF (2004) Gender Equality: The Big Picture, New York: United Nations Children's Fund Vaidyanathan, A. (1999) Water Resource Management: Institutions and Irrigation Development in India, New Delhi: Oxford University Press

York, R. and Egras, C. (2011) 'Women's Status and World-System Position: An Exploratory Analysis', Journal of World-Systems Research 17: 147-64 